OPEN ACCESS

Edited by:

Dongri Song,

Institute of Mountain Hazards and Environment (CAS), China

Reviewed by: Ming Peng,

Tongji University, China

Gang Fan,

Sichuan University, China

*Correspondence:

Qiming Zhong

qmzhong@nhri.cn

Specialty section:

This article was submitted to

Geohazards and Georisks,

a section of the journa

Frontiers in Earth Science

Received: 22 October 2021 Accepted: 02 December 2021

Published: 22 December 2021

Citation:

Yang $M$, Zhong $Q$, Mei S and Shan Y (2021) Influences of Spillway Section

Morphologies on Landslide

Dam Breaching.

Front. Earth Sci. 9:799742.

doi: 10.3389/feart.2021.799742

\section{Influences of Spillway Section Morphologies on Landslide Dam Breaching}

\author{
Meng Yang ${ }^{1}$, Qiming Zhong ${ }^{1,2 *}$, Shengyao $\mathrm{Mei}^{1}$ and Yibo Shan ${ }^{1}$ \\ ${ }^{1}$ Department of Geotechnical Engineering, Nanjing Hydraulic Research Institute, Nanjing, China, ${ }^{2}$ Key Laboratory of Reservoir \\ Dam Safety of the Ministry of Water Resources, Nanjing, China
}

Spillway excavation is often adopted as a precautionary engineering measure for disaster mitigation before landslide dam breaching. Based on the landslide dam breach mechanisms, this paper focuses on developing a numerical model to comprehensively discuss the issue based on three documented landslide dam failures, such as Tangjiashan, Xiaogangjian, and Baige landslide dams. The spillway cross section morphologies were modeled with different sizes under common shape (i.e., an inverted trapezoid) and slope conditions. The influence of cross section on dam breach processes was analyzed under conditions of different depth, bottom width, slope ratio in the cross and longitudinal sections, with/without spillway. The following conclusions can be drawn: 1) excavation of a spillway can effectively reduce the peak breach flow, therefore delay the time to peak; 2) the peak breach flow dramatically decreases and the time to peak delays as the spillway depth increases; 3 ) the peak breach flow changes little and the time to peak occurs earlier with the increment in spillway bottom width; 4) the peak breach flow decreases and the time to peak delays with the decrease of slope ratio in cross section in the spillway; 5) the slope ratio in the longitudinal section has little influence on the breach process. Hence, if conditions permit, the spillway with large spillway depth, small bottom width, and gentle slope ratio in the cross section is the preferable section morphology for the emergency disposal of the landslide dam.

Keywords: landslide dam breaching, spillway, section type, numerical simulation, comparative analysis, risk mitigation

\section{INTRODUCTION}

Landslide dam is formed by mass movements of rock and debris blocking the river channel due to earthquakes and intense rainfall (Costa and Schuster, 1988); Figure 1 presents the Hongshiyan landslide dam that occurred on August 3rd, 2014 in China. The landslide dam stability is usually related to grainsize distribution of landslide debris, landslide volume, and hydrodynamic conditions (Liao et al., 2019; Shan et al., 2020; Peng et al., 2021). Dissimilar to artificial dams, landslide dams do not have a structure that enables flood discharge (Zhong et al., 2021). The water level in the dammed lake increases eventually after the landslide dam formation due to the continuous inflow from the upstream; hence, overtopping is the most common cause of failure mode for the dam (Zhong et al., 2018).

The failure of a landslide dam may pose a tremendous threat to human life and property in the downstream region; hence, risk mitigation of landslide dam failure has significant implications for socio-economic development. The risk mitigation measures for landslide dams can be categorized 


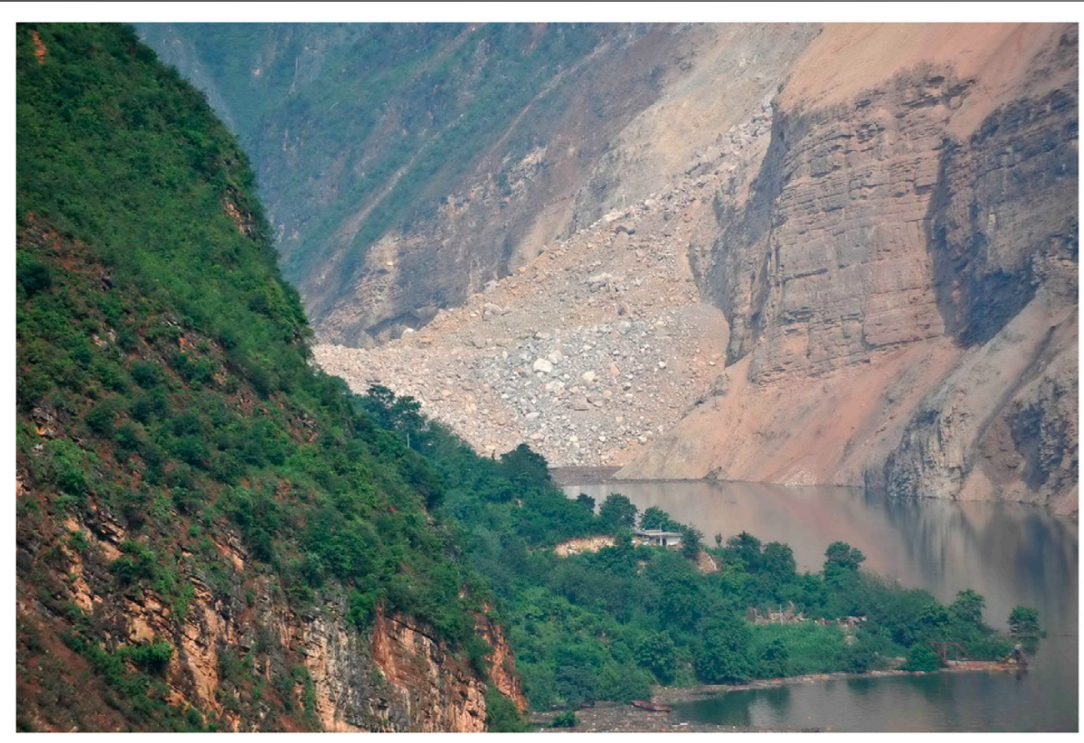

FIGURE 1 | Hongshiyan landslide dam in China.

into engineering and non-engineering. Non-engineering measures include warning and evacuation of people in the risk area, whilst engineering measures consist of reducing the landslide dam height or/and the reservoir of the dammed lake to minimize downstream hazards. In general, engineering measures are usually taken immediately, if conditions permit, to prevent the water level from reaching dangerous elevation and to reduce the reservoir capacity. In the current situation, commonly used engineering measures are basically the construction of drainage tunnels through abutments, installing drainage conduits, and excavating spillways through dams (Schuster and Evans, 2011; Peng et al., 2014) (Figure 2). Constructing a drainage tunnel is usually expensive and timeconsuming, and also the transportation of apparatuses and materials requires certain external conditions to be provided. Installing a drainage conduit is less affordable and more effortless than constructing a drainage tunnel; however, it has a relatively lower discharge capacity; nevertheless, it is often used to deal with landslide dams with a small reservoir. In contrast to other methods, excavating a spillway is a more efficient way to prevent the rising water level and reduce the storage capacity, which does not require complex external conditions and is relatively convenient to construct; hence, it has become forward as the most common engineering measure for the risk mitigation of landslide dams (Peng et al., 2014).

In the literature, there are several applicable cases regarding the excavation of spillways through landslide dams that have been utilized in risk mitigation. On April 25th, 1974, a large landslide with a total volume of $1,000-1,300 \times 106 \mathrm{~m}^{3}$ took place in Mayumarca Valley, Peru, and then a landslide dam formed with the volume of about $800 \times 106 \mathrm{~m}^{3}$; the dammed lake was about $32 \mathrm{~km}$ long and contained the reservoir over $670 \times 106 \mathrm{~m}^{3}$ (Berrocal et al., 1978). To minimize the potential flood damage, a spillway with $3 \mathrm{~m}$ depth and $250 \mathrm{~m}$ length was excavated (Cai et al., 2021). On April 9th, 2000, a huge rock avalanche occurred at the Yigong Village of Tibet (Shang et al., 2003), formed landslide debris transported $8-10 \mathrm{~km}$ with high velocity, and completely blocked the Yigong Zangpo River. The length, width, and height of the landslide dam were $2.5 \mathrm{~km}, 2.5 \mathrm{~km}$, and $60-110 \mathrm{~m}$, respectively. Subsequently, a spillway with $30 \mathrm{~m}$ depth and $30 \mathrm{~m}$ bottom width was excavated before dam breaching, which significantly reduced the reservoir of dammed lake. Furthermore, 37 high-risk landslide dams formed by the Wenchuan Earthquake in 2008, China, were eliminated through excavating spillways (Cui et al., 2009; Yin et al., 2009; Peng et al., 2014).

The most crucial consideration for spillway excavation is efficiently reducing the maximum storage capacity of dammed lake and the breach flow discharge to mitigate the disaster in the downstream area. The majority of the landslide dams are formed in the mountainous regions with restricted transportation and breached within a short time. As a consequence, it is vital to completely consider the rate of rising of the water level in the dammed lake, the limitations of the construction conditions, and the discharge capacity of the downstream river channel, and to optimize the design of the spillway section morphology.

The current study offers a novel numerical model developed by the authors to quantitatively compare the breach hydrograph and breach size evolution process for each spillway section morphology. It is worth mentioning that, in this study, the cross section of spillway is specified as an inverted trapezoid in the numerical modeling due to the challenge in excavating the compound spillway and other section morphologies within a restricted time frame in reality (Figure 3). In the following sections, a brief introduction on the breach mechanisms and numerical model developed by the authors are presented. The influences on the landslide breach process under the conditions of different depth, bottom width, slope ratio in the cross and longitudinal sections, with/without spillway were comprehensively discussed. 


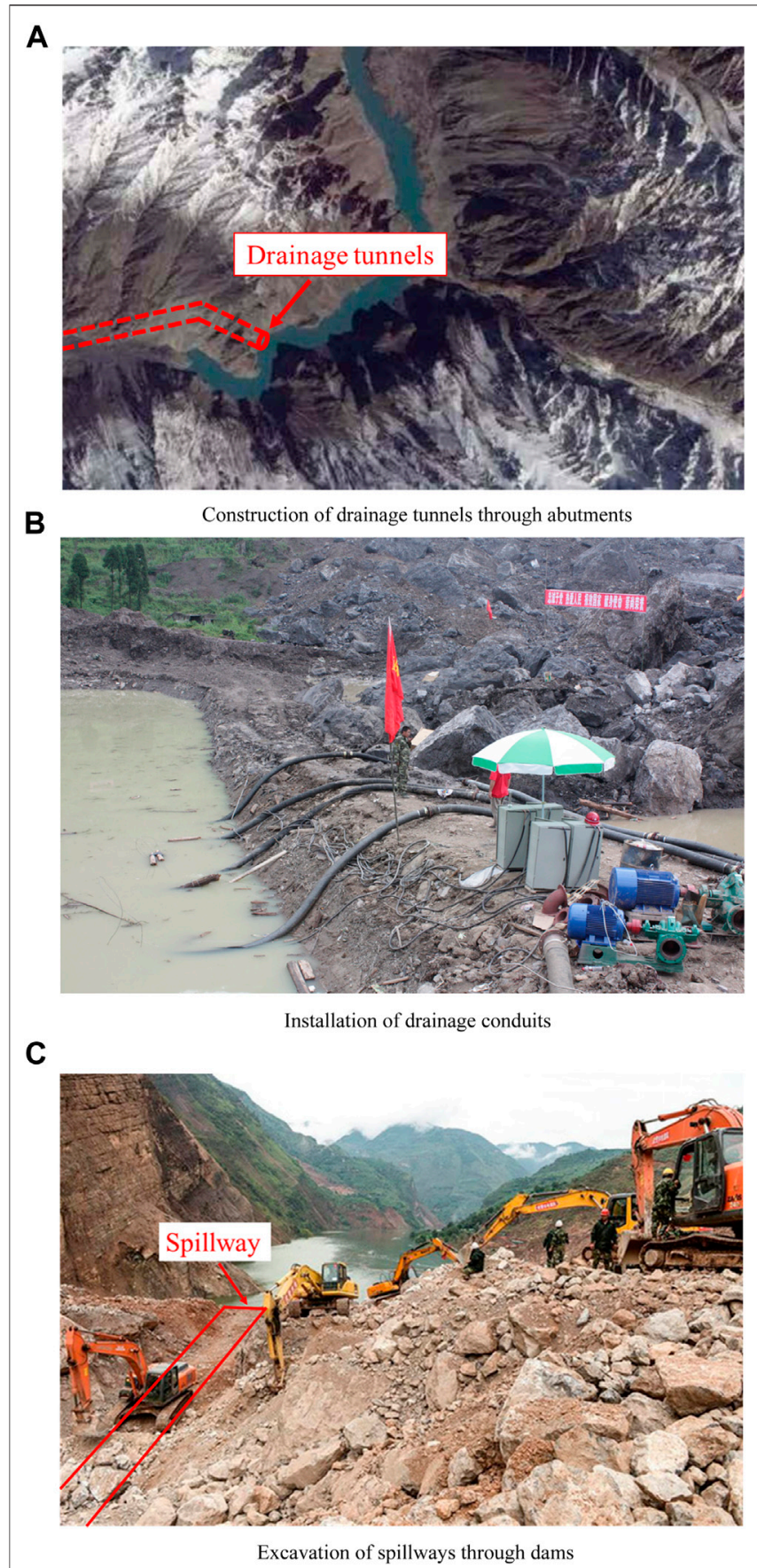

FIGURE 2 | Engineering measures for landslide dam risk mitigation.

\section{BREACH MECHANISMS AND PROCESSES OF OVERTOPPING-INDUCED LANDSLIDE DAMS' BREACHING}

Until recently, numerous model tests on landslide dam breaching have been conducted, such as small-scale flume model tests (Yang et al., 2015; Zhou et al., 2019; Zhu et al.,
2021), large-scale field model tests (Li et al., 2021; Takayama et al., 2021; Zhang et al., 2021), centrifugal model tests (Zhao et al., 2019), and in-situ measurements (Liu et al., 2010; Cai et al., 2020). Although different classification techniques existed in the division of the landslide dam breach process, the outburst process as a whole can be divided into three stages: initiation, acceleration, and stabilization. Further, the phenomenon of backward erosion is founded in the initiation stage; the acceleration stage occurs after the backward erosion enters the upstream dammed lake. The stabilization stage occurs when the inflow and outflow rates are balanced. Admittedly, the large-scale landslide dam breach model tests were only performed on the dam with a height of $1 \mathrm{~m}$ to several meters. Hence, due to the scale effect, the model tests have the following disadvantages: 1) the material composition of landslide dam deposits is relatively uniform, and the particle size of materials is considerably smaller than the actual situation. 2) The majority of the model tests have not considered the structural characteristics of landslide dams. Notwithstanding, the landslide dam breach process is preliminarily demystified and quantitatively documented based on the model tests.

In recent years, several physical model tests have been conducted to investigate the influences of spillway on the breach process of landslide dams. With this regard, the cross section of the spillway is set based on different geometries as an inverted trapezoid, a triangle, or a compound type (the upper part is an inverted trapezoid, and the bottom of the trapezoid is connected with an inverted triangle), shown as Figure 3. Zhao et al. (2011) defined the discharge efficiency, in which the high efficiency means the high increase rate of breach flow discharge or the short elapsed time for the arrival of peak breach flow. Based on the comparison of different model tests, Zhao et al. (2011) stated that the descending order of the discharge efficiencies of spillways is as follows: triangle, compound type, and inverted trapezoid; therewithal, suggested the compound type in the design of spillway for the emergency treatment. However, variations in the cross section areas of the spillways caused differences in the three groups of model tests. Therefore, it is debatable whether the test results can truly reflect the breach hydrographs, even under the condition that the excavated volumes are the same. Later, Zhao et al. (2018) conducted the centrifugal model tests under the condition of the same cross section area and found that the compound section is a relatively safer morphology for the spillway considering the higher initial discharge efficiency and lower peak breach flow. Due to the different environment and equipment, the physical model tests have concluded different results, the results can only reflect the breach process of landslide dam in a certain extent. The spillway with different sections has its own advantages under different conditions, it is difficult to form a unified result based on the same understanding.

The complex material and structural characteristics of landslide dams bring difficulties to accurately reflect the grainsize distribution and layered structure in the model tests; hence, a significant gap exists between the experimental results and the 


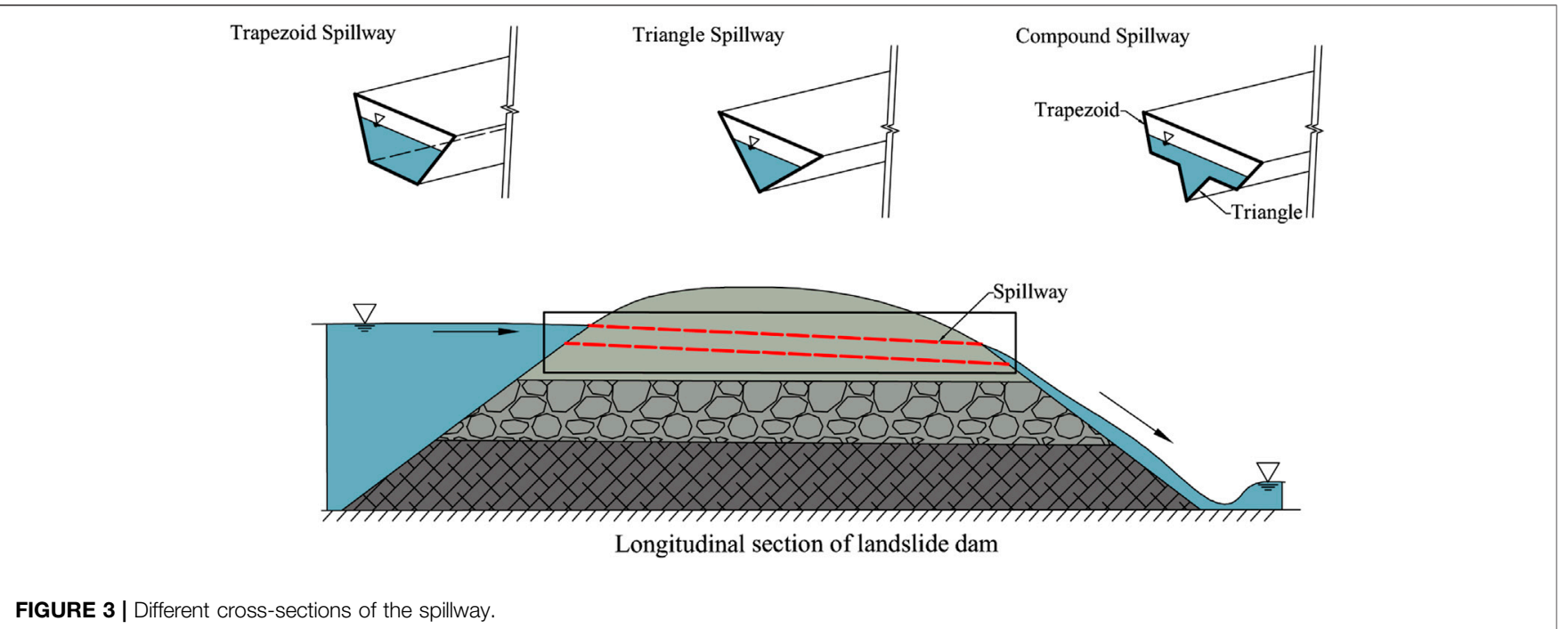

FIGURE 3 | Different cross-sections of the spillway.

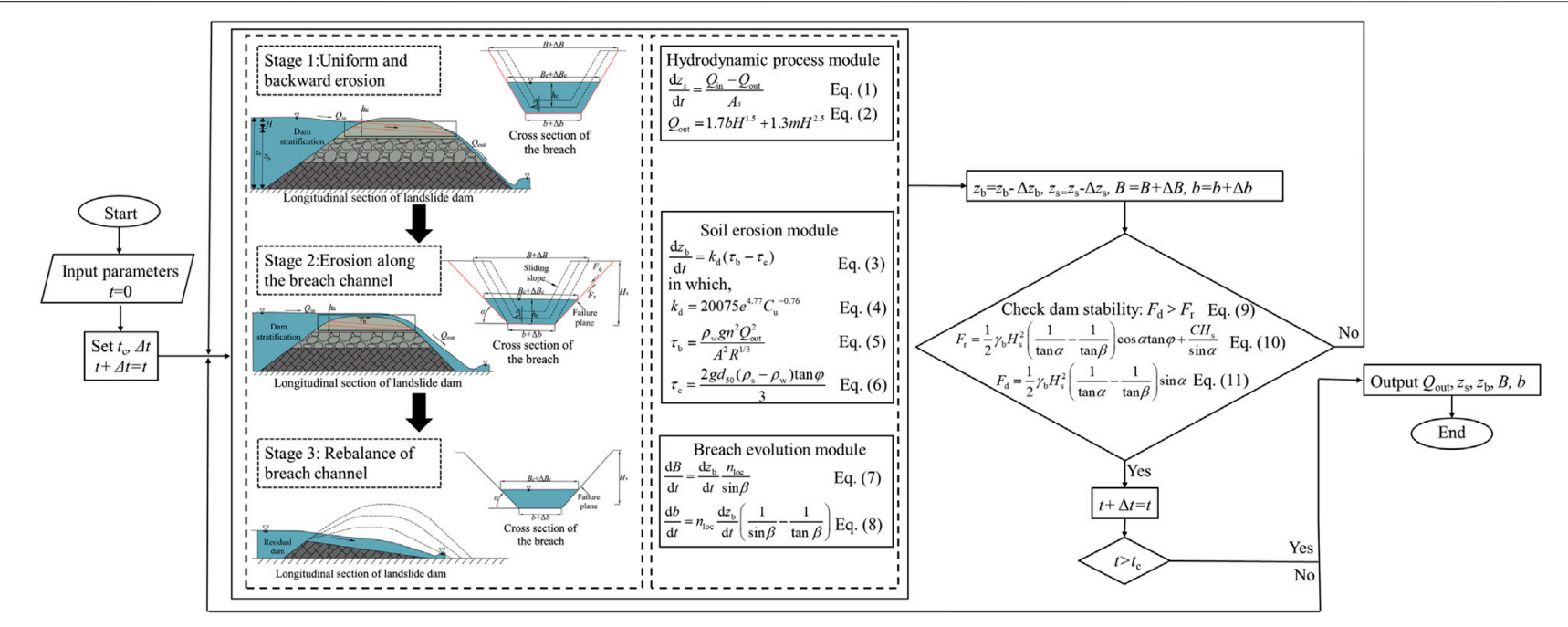

FIGURE 4 | Flow chart of the numerical model for landslide dam breaching.

real state. Numerical analysis is particularly advantageous considering the repeatability and time-saving features as simulating the discharge efficiency of the spillway with different section morphologies based on the same numerical method. Furthermore, numerical methods are widely adopted to scientifically design and quantitatively analyze the breach hydrograph and morphological evolution of landslide dams with different spillway section morphologies. You et al. (2012) proposed an optimized design method of trapezoidal cross section based on the Chezy-manning formula; however, the variation of the hydrodynamic conditions was not considered due to the enlargement of spillway cross section by the flow erosion. Based on the dam breach model DABA, Peng et al. (2014) investigated the applicability of various inverted trapezoidal spillways to different erosive landslide dams. It was concluded that with regard to the erosion resistance of landslide deposits, wide and shallow sections were suitable for low erosion, while the narrow and deep sections were suitable for high erosion. In another study, Shi et al. (2016) presented an optimal design scheme of the spillway based on the calculation of the instantaneous erosion rate of landslide dam and analysis of the influence of spillway on dam breach process, Shi et al. (2016) concluded that compared the compound cross section, the trapezoid cross section has a better risk mitigation effect. However, Chen S. S. et al. (2015) came to the opposite conclusion based the interaction between coarse and fine particles. To the best of the authors' knowledge, no scientific consensus regarding numerical modeling of landslide dam breaching has been established, different results were concluded by research scholar based different situation. 
TABLE 1 | Morphological, hydrodynamic, and mechanical parameters of the three landslide dams.

\section{Parameters}

Dam height $(\mathrm{m})$

Crest width $(\mathrm{m})$

Dam length (m)

Dam upstream slope ratio $(\mathrm{V} / \mathrm{H})$

Dam downstream slope ratio $(\mathrm{V} / \mathrm{H})$

Spillway depth (m)

Spillway bottom width (m)

Spillway slope ratio in cross section $(V / H)$

Spillway slope ratio in longitudinal section $(V / H)$

$Q_{\text {in }}\left(\mathrm{m}^{3} / \mathrm{s}\right)$

$\mathrm{C}(\mathrm{kPa})$

$\varphi\left(^{\circ}\right)$

$V / H=$ Vertical/Horizontal.

\section{Tangjiashan}

103
300
612
$1: 2.8$
$1: 4.2$
13
8
$1: 1.5$
$1: 4.2$
80
30
35

\section{Xiaogangjian}

72
80
300
$1: 2.8$
$1: 1.7$
8
30
$1: 2.0$
$1: 1.7$
15
42
35

Baige

96

270

600

$1: 2.7$

$1: 5.5$

13.48

3.0

$1: 1.3$

$1: 5.5$

700

3

38

TABLE 2 | Stratification of the three landslide dams and the physical/mechanical parameters of each layer.

\begin{tabular}{|c|c|c|c|c|c|c|c|}
\hline Name & Layer & Thickness (m) & $e$ & $d_{50}(\mathrm{~mm})$ & $\rho_{s}\left(\mathrm{~kg} / \mathrm{m}^{3}\right)$ & $k_{d}\left(\mathrm{~mm}^{3} /(\mathrm{N} \cdot \mathrm{s})\right)$ & $\tau_{c}(\mathrm{~Pa})$ \\
\hline \multirow[t]{3}{*}{ Tangjiashan } & 1 & 20 & 0.87 & 10 & 1825 & 1770 & 375 \\
\hline & 2 & 20 & 0.75 & 20 & 2,216 & 700 & 500 \\
\hline & 3 & 63 & 0.59 & 60 & 2,408 & 100 & 1750 \\
\hline \multirow[t]{2}{*}{ Xiaogangjian } & 1 & 32 & 0.94 & 60 & 2045 & 900 & 457 \\
\hline & 2 & 40 & 0.70 & 18 & 1813 & 300 & 200 \\
\hline Baige & 1 & 96 & 0.5 & 30 & 1,584 & 1,500 & 2,380 \\
\hline
\end{tabular}

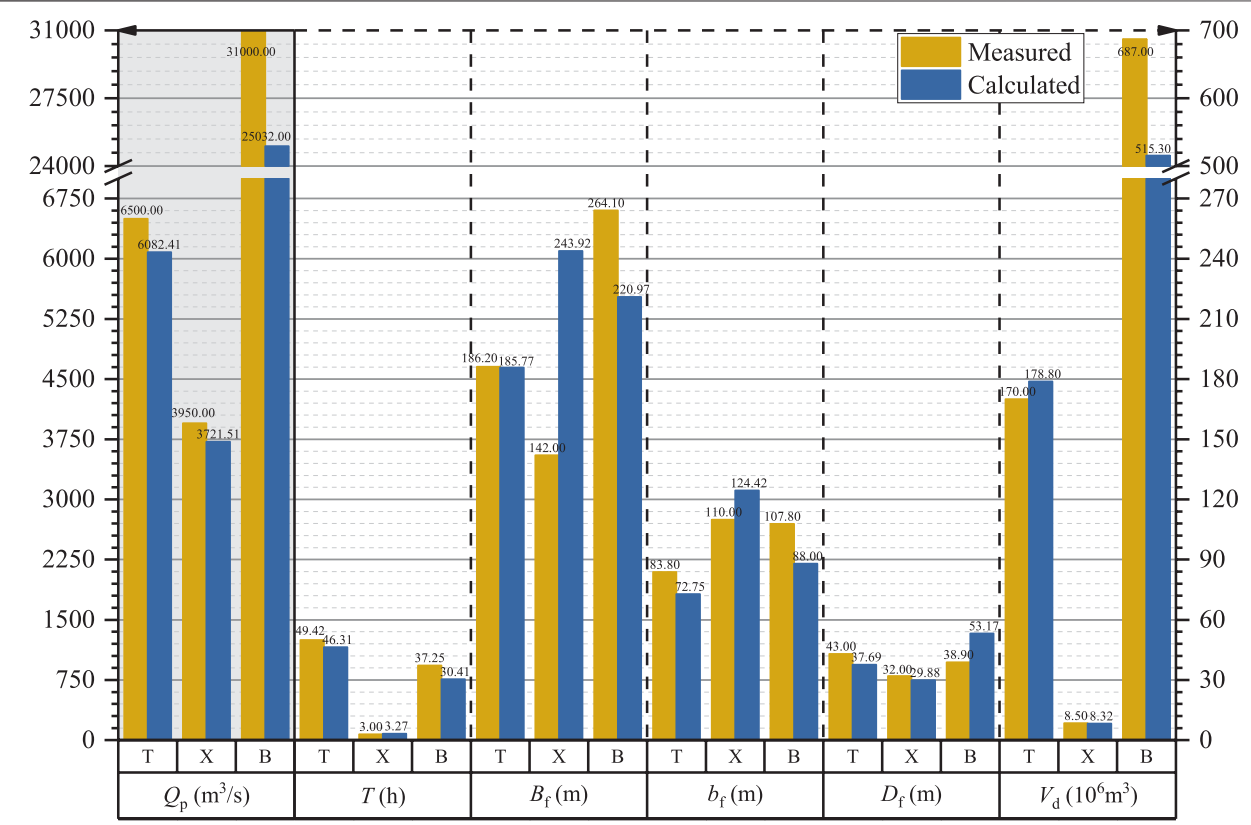

FIGURE 5 | Comparison of calculated and measured breaching parameters of the three landslide dams ( $T=$ Tangjiashan landslide dam; $X=$ Xiaogangjian landslide dam; $B=$ Baige landslide dam; $Q_{p}=$ peak breach flow; $T_{p}=$ time to peak; $B_{f}=$ final breach top width; $b_{f}=$ final breach bottom width; $D_{f}=$ final breach depth; and $V_{d}=$ released water volume. Herein, $Q_{p}$ of the three dams are corresponding to the left axis, and the other indicators correspond to the right axis). 
TABLE 3 | Morphological parameters of the spillways with different section types.

\begin{tabular}{|c|c|c|c|c|c|}
\hline Landslide name & Condition & Depth (m) & $\begin{array}{l}\text { Bottom width } \\
\text { (m) }\end{array}$ & $\begin{array}{l}\text { Slope ratio } \\
\text { in cross } \\
\text { section }\end{array}$ & $\begin{array}{c}\text { Slope ratio } \\
\text { in longitudinal } \\
\text { section }\end{array}$ \\
\hline \multirow[t]{10}{*}{ Tangjiashan } & 1 & 13.00 & 8.0 & $1: 1.5$ & $1: 4.2$ \\
\hline & 2 & - & - & - & - \\
\hline & 3 & 15.00 & 8.0 & $1: 1.5$ & $1: 4.2$ \\
\hline & 4 & 17.00 & 8.0 & $1: 1.5$ & $1: 4.2$ \\
\hline & 5 & 13.00 & 4.0 & $1: 1.5$ & $1: 4.2$ \\
\hline & 6 & 13.00 & 16.0 & $1: 1.5$ & $1: 4.2$ \\
\hline & 7 & 13.00 & 8.0 & $1: 2.0$ & $1: 4.2$ \\
\hline & 8 & 13.00 & 8.0 & $1: 2.5$ & $1: 4.2$ \\
\hline & 9 & 13.00 & 8.0 & $1: 1.5$ & $1: 3.2$ \\
\hline & 10 & 13.00 & 8.0 & $1: 1.5$ & $1: 5.2$ \\
\hline \multirow[t]{10}{*}{ Xiaogangjian } & 1 & 8.00 & 30.0 & $1: 2.0$ & $1: 1.7$ \\
\hline & 2 & - & - & - & - \\
\hline & 3 & 9.00 & 30.0 & $1: 2.0$ & $1: 1.7$ \\
\hline & 4 & 10.00 & 30.0 & $1: 2.0$ & $1: 1.7$ \\
\hline & 5 & 8.00 & 20.0 & $1: 2.0$ & $1: 1.7$ \\
\hline & 6 & 8.00 & 40.0 & $1: 2.0$ & $1: 1.7$ \\
\hline & 7 & 8.00 & 30.0 & $1: 2.5$ & $1: 1.7$ \\
\hline & 8 & 8.00 & 30.0 & $1: 3.0$ & $1: 1.7$ \\
\hline & 9 & 8.00 & 30.0 & $1: 2.0$ & $1: 1.5$ \\
\hline & 10 & 8.00 & 30.0 & $1: 2.0$ & $1: 1.9$ \\
\hline \multirow[t]{10}{*}{ Baige } & 1 & 13.48 & 3.0 & $1: 1.3$ & $1: 5.5$ \\
\hline & 2 & - & - & - & - \\
\hline & 3 & 18.48 & 3.0 & $1: 1.3$ & $1: 5.5$ \\
\hline & 4 & 23.48 & 3.0 & $1: 1.3$ & $1: 5.5$ \\
\hline & 5 & 13.48 & 1.0 & $1: 1.3$ & $1: 5.5$ \\
\hline & 6 & 13.48 & 6.0 & $1: 1.3$ & $1: 5.5$ \\
\hline & 7 & 13.48 & 3.0 & $1: 1.6$ & $1: 5.5$ \\
\hline & 8 & 13.48 & 3.0 & $1: 1.9$ & $1: 5.5$ \\
\hline & 9 & 13.48 & 3.0 & $1: 1.3$ & $1: 5.0$ \\
\hline & 10 & 13.48 & 3.0 & $1: 1.3$ & $1: 6.0$ \\
\hline
\end{tabular}

\section{NUMERICAL MODEL FOR OVERTOPPING-INDUCED LANDSLIDE DAM BREACHING}

In the previous section, the landslide dam failure process, in detail overtopping-induced landslide dam breach process, can be generally classified into three stages according to the results of the research: 1) Uniform and backward erosion. As the upstream water level continues to rise, the overtopping flow enters into the spillway entrance, and then the spillway is gradually filled with water. Since the flow velocity is relatively small, the erosion mode is mainly characterized by uniform erosion. With the increase of water depth and velocity in the spillway, intense erosion primarily occurs at the downstream toe of the landslide dam; subsequently, backward erosion begins until it reaches the dammed lake. 2) Erosion along the breach channel. After the erosion reached the dammed lake, the overtopping water head abruptly increased, then the flow velocity and breach flow discharge continue to rise rapidly. During the elapsed time, the bottom elevation of the breach channel also decreases rapidly. The downstream slope angle gradually decreases due to the erosion by water flow; simultaneously, the breach slope is intermittently unstable, and the peak breach flow occurs in this period. 3) Rebalance of breach channel. The water level in the dammed lake begins to decline rapidly with the increase of the breach flow discharge; thus, the breach channel has gained sufficient discharge capacity, resulting in at the end of the breach process.

Based on the breach process, a numerical model that can consider the hydrodynamic conditions of the dammed lake, the morphological, structural, and material characteristics of the landslide dam was proposed by Zhong et al. (2020a). The model consisted of three parts: the hydrodynamic process module, the soil erosion module, and the breach evolution module. The flow chart of the numerical model was created using the time step iteration-based calculation method to simulate the water and soil connection during the dam failure process is shown in Figure 4.

\section{The Hydrodynamic Process Module}

The water level in the dammed lake is a dynamic process during landslide dam breaching. The lake area, inflow and different water level under different time should be considered to calculating the discharge flow, the breach process obey the water balance relationship.

$$
\begin{gathered}
\frac{\mathrm{d} z \mathrm{~s}}{\mathrm{~d} t}=\frac{Q_{\text {in }}-Q_{\text {out }}}{A s} \\
Q_{\text {out }}=1.7 b H^{1.5}+1.3 m H^{2.5}
\end{gathered}
$$


TABLE 4 | Comparison of calculated results of Tangjiashan landslide dam under different conditions.

\begin{tabular}{|c|c|c|c|c|c|c|c|}
\hline Condition & Comparison & $\begin{array}{c}\text { Peak } \\
\text { breach flow } \\
\left(\mathrm{m}^{3} / \mathrm{s}\right)\end{array}$ & $\begin{array}{l}\text { Time to } \\
\text { peak (h) }\end{array}$ & $\begin{array}{l}\text { Final breach top } \\
\text { width } \\
\text { (m) }\end{array}$ & $\begin{array}{l}\text { Final breach bottom } \\
\text { width } \\
\text { (m) }\end{array}$ & $\begin{array}{c}\text { Final } \\
\text { breach } \\
\text { depth (m) }\end{array}$ & $\begin{array}{c}\text { Released water } \\
\text { storage } \\
\left(\times 10^{6} \mathrm{~m}^{3}\right)\end{array}$ \\
\hline 1 & Calculated & $6,082.41$ & 46.31 & 185.77 & 72.75 & 37.69 & 178.8 \\
\hline \multirow[t]{2}{*}{2} & Calculated & $16,291.79$ & 17.20 & 240.92 & 88.77 & 41.51 & 279.6 \\
\hline & $\begin{array}{l}\text { Relative change } \\
\text { rate }\end{array}$ & $167.85 \%$ & $-62.86 \%$ & $29.69 \%$ & $22.02 \%$ & $10.14 \%$ & $56.38 \%$ \\
\hline \multirow[t]{2}{*}{3} & Calculated & $4,480.04$ & 60.23 & 175.35 & 65.25 & 36.72 & 160.7 \\
\hline & $\begin{array}{l}\text { Relative change } \\
\text { rate }\end{array}$ & $-26.34 \%$ & $30.06 \%$ & $-5.61 \%$ & $-10.31 \%$ & $-2.57 \%$ & $-10.12 \%$ \\
\hline \multirow[t]{2}{*}{4} & Calculated & $3,106.39$ & 83.48 & 163.59 & 57.18 & 35.49 & 141.9 \\
\hline & $\begin{array}{l}\text { Relative change } \\
\text { rate }\end{array}$ & $-48.93 \%$ & $80.26 \%$ & $-11.94 \%$ & $-21.40 \%$ & $-5.84 \%$ & $-20.64 \%$ \\
\hline \multirow[t]{2}{*}{5} & Calculated & $6,152.18$ & 59.17 & 182.57 & 68.17 & 38.16 & 180.2 \\
\hline & $\begin{array}{l}\text { Relative change } \\
\text { rate }\end{array}$ & $1.15 \%$ & $27.77 \%$ & $-1.72 \%$ & $-6.30 \%$ & $1.25 \%$ & $0.78 \%$ \\
\hline \multirow[t]{2}{*}{6} & Calculated & $6,160.34$ & 38.18 & 193.12 & 82.32 & 36.96 & 176.4 \\
\hline & $\begin{array}{l}\text { Relative change } \\
\text { rate }\end{array}$ & $1.28 \%$ & $-17.56 \%$ & $3.96 \%$ & $13.15 \%$ & $-1.94 \%$ & $-1.34 \%$ \\
\hline \multirow[t]{2}{*}{7} & Calculated & $5,304.97$ & 56.31 & 218.14 & 76.25 & 35.48 & 170.5 \\
\hline & $\begin{array}{l}\text { Relative change } \\
\text { rate }\end{array}$ & $-12.78 \%$ & $21.59 \%$ & $17.42 \%$ & $4.81 \%$ & $-5.86 \%$ & $-4.64 \%$ \\
\hline \multirow[t]{2}{*}{8} & Calculated & $4,624.93$ & 67.07 & 247.24 & 79.96 & 33.46 & 162.5 \\
\hline & $\begin{array}{l}\text { Relative change } \\
\text { rate }\end{array}$ & $-23.96 \%$ & $44.83 \%$ & $33.09 \%$ & $9.91 \%$ & $-11.22 \%$ & $-9.12 \%$ \\
\hline \multirow[t]{2}{*}{9} & Calculated & 6,528.22 & 47.24 & 194.12 & 78.89 & 38.44 & 181.7 \\
\hline & $\begin{array}{l}\text { Relative change } \\
\text { rate }\end{array}$ & $7.33 \%$ & $2.01 \%$ & $4.49 \%$ & $8.44 \%$ & $1.99 \%$ & $1.62 \%$ \\
\hline \multirow[t]{2}{*}{10} & Calculated & $5,650.15$ & 46.62 & 178.29 & 67.74 & 36.87 & 175.6 \\
\hline & $\begin{array}{l}\text { Relative change } \\
\text { rate }\end{array}$ & $-7.11 \%$ & $0.67 \%$ & $-4.03 \%$ & $-6.89 \%$ & $-2.18 \%$ & $-1.79 \%$ \\
\hline
\end{tabular}

where $t=$ time; $z_{\mathrm{s}}=$ water level in dammed lake; $Q_{\text {in }}=$ inflow discharge; $Q_{\text {out }}=$ breach flow discharge; $A_{s}=$ surface area of dammed lake; $H=$ water depth in breach, and $H=z_{\mathrm{s}} z_{\mathrm{b}} ; m=$ ratio of breach slope (horizontal/vertical); and $b=$ bottom width of breach.

\section{The Soil Erosion Module}

The bed erosion in the breach bottom is calculate by a shear stress based erosion rate formula that can simulate the soil with wide grading.

$$
\frac{\mathrm{d} z_{\mathrm{b}}}{\mathrm{d} t}=k_{\mathrm{d}}\left(\tau_{\mathrm{b}}-\tau_{\mathrm{c}}\right)
$$

in which,

$$
\begin{gathered}
k_{\mathrm{d}}=20075 e^{4.77} C_{\mathrm{u}}{ }^{-0.76} \\
\tau_{\mathrm{b}}=\frac{\rho_{\mathrm{w}} g n^{2} Q_{\text {out }}^{2}}{A^{2} R^{1 / 3}} \\
\tau_{\mathrm{c}}=\frac{2 g d_{50}\left(\rho_{\mathrm{s}}-\rho_{\mathrm{w}}\right) \tan \varphi}{3}
\end{gathered}
$$

where $z_{\mathrm{b}}=$ breach bottom elevation; $k_{\mathrm{d}}=$ erodibility coefficient of soil; $\tau_{\mathrm{b}}=$ bed shear stress of water; $\tau_{\mathrm{c}}=$ critical shear stress of soil; $e=$ void ratio of soil, $C_{\mathrm{u}}=$ non-uniformity coefficient; $\rho_{\mathrm{w}}=$ density of water; $\rho_{\mathrm{s}}=$ density of soil; $n=$ Manning's roughness coefficient; $A=$ flow area; $R=$ hydraulic radius; $d_{50}=$ sediment median size; and $\varphi=$ internal friction angle of soil.

\section{The Breach Evolution Module}

It is assumed that the breach side slope angles remain unchanged during the breach process until the instability of the side slopes. The increments of top and bottom widths can be calculated as following:

$$
\begin{gathered}
\frac{\mathrm{d} B}{\mathrm{~d} t}=\frac{\mathrm{d} z_{\mathrm{b}}}{\mathrm{d} t} \frac{n_{\mathrm{loc}}}{\sin \beta} \\
\frac{\mathrm{d} b}{\mathrm{~d} t}=n_{\mathrm{loc}} \frac{\mathrm{d} z_{\mathrm{b}}}{\mathrm{d} t}\left(\frac{1}{\sin \beta}-\frac{1}{\tan \beta}\right)
\end{gathered}
$$

where $B=$ top width of breach; $n_{\mathrm{loc}}=$ indicator of breach location, in which, $n_{\text {loc }}=1$ represents one-sided breach and $n_{\text {loc }}=2$ represents two-sided breach; and $\beta=$ breach side slope angle.

With the development of breach size, instability of breach side slope will occur. The slope stability is calculated by the limit equilibrium method. The slope failure surface is assumed to be a plane, the slope will be instable when the following condition are met:

$$
F_{\mathrm{d}}>F_{\mathrm{r}}
$$

in which,

$$
F_{\mathrm{r}}=\frac{1}{2} \gamma_{\mathrm{b}} H_{\mathrm{s}}^{2}\left(\frac{1}{\tan \alpha}-\frac{1}{\tan \beta}\right) \cos \alpha \tan \varphi+\frac{C H_{\mathrm{s}}}{\sin \alpha}
$$


TABLE 5 | Comparison of calculated results of Xiaogangjian landslide dam under different conditions.

\begin{tabular}{|c|c|c|c|c|c|c|c|}
\hline Condition & Comparison & $\begin{array}{c}\text { Peak } \\
\text { breach flow } \\
\left(\mathrm{m}^{3} / \mathrm{s}\right)\end{array}$ & $\begin{array}{l}\text { Time to } \\
\text { peak (h) }\end{array}$ & $\begin{array}{l}\text { Final breach top } \\
\text { width } \\
\text { (m) }\end{array}$ & $\begin{array}{l}\text { Final breach bottom } \\
\text { width } \\
\text { (m) }\end{array}$ & $\begin{array}{c}\text { Final } \\
\text { breach } \\
\text { depth (m) }\end{array}$ & $\begin{array}{c}\text { Released water } \\
\text { storage } \\
\left(\times 10^{6} \mathrm{~m}^{3}\right)\end{array}$ \\
\hline 1 & Calculated & $3,721.51$ & 3.27 & 243.92 & 124.42 & 29.88 & 8.32 \\
\hline \multirow[t]{2}{*}{2} & Calculated & - & - & - & - & - & - \\
\hline & $\begin{array}{l}\text { Relative change } \\
\text { rate }\end{array}$ & - & - & - & - & - & - \\
\hline \multirow[t]{2}{*}{3} & Calculated & $3,312.15$ & 4.43 & 237.67 & 119.3 & 29.59 & 7.88 \\
\hline & $\begin{array}{l}\text { Relative change } \\
\text { rate }\end{array}$ & $-11.00 \%$ & $35.47 \%$ & $-2.56 \%$ & $-4.12 \%$ & $-0.97 \%$ & $-5.29 \%$ \\
\hline \multirow[t]{2}{*}{4} & Calculated & $2,782.14$ & 9.63 & 231.23 & 114.11 & 29.28 & 7.44 \\
\hline & $\begin{array}{l}\text { Relative change } \\
\text { rate }\end{array}$ & $-25.24 \%$ & $194.50 \%$ & $-5.20 \%$ & $-8.29 \%$ & $-2.01 \%$ & $-10.58 \%$ \\
\hline \multirow[t]{2}{*}{5} & Calculated & $3,810.31$ & 4.47 & 229.63 & 106.78 & 30.71 & 8.44 \\
\hline & $\begin{array}{l}\text { Relative change } \\
\text { rate }\end{array}$ & $2.39 \%$ & $36.70 \%$ & $-5.86 \%$ & $-14.18 \%$ & $2.78 \%$ & $1.44 \%$ \\
\hline \multirow[t]{2}{*}{6} & Calculated & $3,716.76$ & 2.75 & 258.29 & 141.92 & 29.09 & 8.2 \\
\hline & $\begin{array}{l}\text { Relative change } \\
\text { rate }\end{array}$ & $-0.13 \%$ & $-15.90 \%$ & $5.89 \%$ & $14.07 \%$ & $-2.64 \%$ & $-1.44 \%$ \\
\hline \multirow[t]{2}{*}{7} & Calculated & $3,272.61$ & 4.1 & 270.02 & 130 & 28.01 & 8.01 \\
\hline & $\begin{array}{l}\text { Relative change } \\
\text { rate }\end{array}$ & $-12.06 \%$ & $25.38 \%$ & $10.70 \%$ & $4.48 \%$ & $-6.26 \%$ & $-3.73 \%$ \\
\hline \multirow[t]{2}{*}{8} & Calculated & $2,775.38$ & 5.12 & 293.74 & 135.44 & 26.36 & 7.71 \\
\hline & $\begin{array}{l}\text { Relative change } \\
\text { rate }\end{array}$ & $-25.42 \%$ & $56.57 \%$ & $20.42 \%$ & $8.86 \%$ & $-11.78 \%$ & $-7.33 \%$ \\
\hline \multirow[t]{2}{*}{9} & Calculated & $3,740.39$ & 3.39 & 247.82 & 128.15 & 29.90 & 8.33 \\
\hline & $\begin{array}{l}\text { Relative change } \\
\text { rate }\end{array}$ & $0.51 \%$ & $3.67 \%$ & $1.60 \%$ & $3.00 \%$ & $0.07 \%$ & $0.12 \%$ \\
\hline \multirow[t]{2}{*}{10} & Calculated & $3,692.49$ & 3.18 & 240.13 & 120.91 & 29.81 & 8.31 \\
\hline & $\begin{array}{l}\text { Relative change } \\
\text { rate }\end{array}$ & $-0.78 \%$ & $-2.75 \%$ & $-1.55 \%$ & $-2.82 \%$ & $-0.23 \%$ & $-0.12 \%$ \\
\hline
\end{tabular}

$$
F_{\mathrm{d}}=\frac{1}{2} \gamma_{\mathrm{b}} H_{\mathrm{s}}^{2}\left(\frac{1}{\tan \alpha}-\frac{1}{\tan \beta}\right) \sin \alpha
$$

where $F_{\mathrm{d}}=$ driving force; $F_{\mathrm{r}}=$ resistant force; $\gamma_{\mathrm{b}}=$ bulk specific weight of soil; $H_{\mathrm{s}}=$ breach slope height; $\alpha=$ breach side slope angle after instability; and $C=$ soil cohesion.

\section{CASE STUDIES}

\section{The Classification of Landslide Dams}

The landslide dams' body is formed by the accumulation of landslide debris; its structure and constituents are strongly associated with the movement and material composition of slide mass. The rock slides, rock falls, and debris flows are the most prominent forms of slides that lead to the formation of landslide dams (Fan et al., 2020; Mei et al., 2021). 1) Rock slides are a phenomenon that results in rocks sliding and blocking the river when the driving force on a potential failure surface surpasses the resistance force. Due to the limited movement distance, the sliding rocks often do not completely disintegrate, a portion of which still retain the original structure. The internal structure of landslide dams formed due to rock slides can be divided into two or more layers that have a structure in which the particle sizes of landslide deposits increase gradually with the depth. Depth-dependent particle size variation results in the landslide dam base being composed of intact strata, while the upper sections have a fragmented fraction of rock debris and soil. 2) Rock falls, as another phenomenon that causes the landslide dam formation, occurs when the rock slope loses stability under external loads; subsequently, the upper rock and soil drop by falling, leaping, or rolling. The internal structure can be split into two layers due to the various movement directions of rocks and soils; the bottom layer is composed of highly fragmented rock debris and fine-grained soil, while the top layer is composed of large-grained rocks. 3) Debris flows can be defined as the accumulation of the loose materials on the river channel derived due to the disintegration of large rock particles under high-speed sliding action and mutual collision after an avalanche occurs at the high elevation of the rock slope. Therefore, landslide dams formed by debris flows are typically dominated by relatively loose particles and fine-grained soil rather than rock structures.

In this section, corresponding to the landslide dams of the three types, three landslide dam failure cases, such as Tangjiashan (Liu et al., 2010; Chen Z. Y. et al., 2015), Xiaogangjian (Chen et al., 2018), and Baige (Cai et al., 2020; Zhong et al., 2020b) in China with documented information on the breach process are chosen as the representatives.

\section{Introduction of the Three Landslide Dams}

Tangjiashan landslide dam was formed by Wenchuan earthquake on May 12, 2008, China. Based on the geological investigation, the landslide dam belongs to the first type (rock slide induced) of 
TABLE 6 | Comparison of calculated results of Baige landslide dam under different conditions.

\begin{tabular}{|c|c|c|c|c|c|c|c|}
\hline Condition & Comparison & $\begin{array}{c}\text { Peak } \\
\text { breach flow } \\
\left(\mathrm{m}^{3} / \mathrm{s}\right)\end{array}$ & $\begin{array}{l}\text { Time to } \\
\text { peak (h) }\end{array}$ & $\begin{array}{l}\text { Final breach top } \\
\text { width } \\
\text { (m) }\end{array}$ & $\begin{array}{l}\text { Final breach bottom } \\
\text { width } \\
(\mathrm{m})\end{array}$ & $\begin{array}{c}\text { Final } \\
\text { breach } \\
\text { depth }(m)\end{array}$ & $\begin{array}{c}\text { Released water } \\
\text { storage } \\
\left(\times 10^{6} \mathrm{~m}^{3}\right)\end{array}$ \\
\hline 1 & Calculated & $25,032.00$ & 30.41 & 220.97 & 88.0 & 53.17 & 515.3 \\
\hline \multirow[t]{2}{*}{2} & Calculated & $80,569.91$ & 16.28 & 367.76 & 141.43 & 90.53 & 726 \\
\hline & $\begin{array}{l}\text { Relative change } \\
\text { rate }\end{array}$ & $221.87 \%$ & $-46.46 \%$ & $66.43 \%$ & $60.72 \%$ & $70.27 \%$ & $40.89 \%$ \\
\hline \multirow[t]{2}{*}{3} & Calculated & $15,743.74$ & 47.97 & 196.44 & 70.95 & 50.19 & 397.79 \\
\hline & $\begin{array}{l}\text { Relative change } \\
\text { rate }\end{array}$ & $-37.11 \%$ & $57.74 \%$ & $-11.10 \%$ & $-19.38 \%$ & $-5.61 \%$ & $-22.80 \%$ \\
\hline \multirow[t]{2}{*}{4} & Calculated & $9,151.75$ & 52.78 & 170.11 & 53.15 & 46.78 & 278.8 \\
\hline & $\begin{array}{l}\text { Relative change } \\
\text { rate }\end{array}$ & $-63.44 \%$ & $73.56 \%$ & $-23.02 \%$ & $-39.60 \%$ & $-12.02 \%$ & $-45.90 \%$ \\
\hline \multirow[t]{2}{*}{5} & Calculated & $26,254.34$ & 35.75 & 221.56 & 86.70 & 53.94 & 518.2 \\
\hline & $\begin{array}{l}\text { Relative change } \\
\text { rate }\end{array}$ & $4.88 \%$ & $17.56 \%$ & $0.27 \%$ & $-1.48 \%$ & $1.45 \%$ & $0.56 \%$ \\
\hline \multirow[t]{2}{*}{6} & Calculated & $24,069.06$ & 25.84 & 221.80 & 90.80 & 52.40 & 512.3 \\
\hline & $\begin{array}{l}\text { Relative change } \\
\text { rate }\end{array}$ & $-3.85 \%$ & $-15.03 \%$ & $0.38 \%$ & $3.18 \%$ & $-1.45 \%$ & $-0.58 \%$ \\
\hline \multirow[t]{2}{*}{7} & Calculated & $22,993.6$ & 31.73 & 251.88 & 90.18 & 50.53 & 504.2 \\
\hline & $\begin{array}{l}\text { Relative change } \\
\text { rate }\end{array}$ & $-8.14 \%$ & $4.34 \%$ & $13.99 \%$ & $2.48 \%$ & $-4.97 \%$ & $-2.15 \%$ \\
\hline \multirow[t]{2}{*}{8} & Calculated & $21,257.8$ & 32.98 & 276.02 & 92.49 & 48.27 & 493.8 \\
\hline & $\begin{array}{l}\text { Relative change } \\
\text { rate }\end{array}$ & $-15.08 \%$ & $8.45 \%$ & $24.91 \%$ & $5.10 \%$ & $-9.22 \%$ & $-4.17 \%$ \\
\hline \multirow[t]{2}{*}{9} & Calculated & $26,407.68$ & 30.09 & 227.21 & 91.72 & 54.20 & 519.6 \\
\hline & $\begin{array}{l}\text { Relative change } \\
\text { rate }\end{array}$ & $5.50 \%$ & $-1.05 \%$ & $2.82 \%$ & $4.23 \%$ & $1.94 \%$ & $0.83 \%$ \\
\hline \multirow[t]{2}{*}{10} & Calculated & $23,824.84$ & 30.79 & 215.45 & 84.81 & 52.26 & 511.2 \\
\hline & $\begin{array}{l}\text { Relative change } \\
\text { rate }\end{array}$ & $-4.82 \%$ & $1.25 \%$ & $-2.50 \%$ & $-3.63 \%$ & $-1.71 \%$ & $-0.80 \%$ \\
\hline
\end{tabular}

landslide dams; further, it has three internal layers from dam crest to bottom, which are composed of fine-grained soils, layered fractured rock mass, and block rock mass, respectively. Tangjiashan landslide dam has the height of about $103 \mathrm{~m}$, and width of $300 \mathrm{~m}$ on the crest, and a volume of $2.04 \times 107 \mathrm{~m}^{3}$. After the emergency response from May 26 to May 31, a spillway with the depth of $13 \mathrm{~m}$ and bottom width of $8 \mathrm{~m}$ was excavated on the right bank of the dam. The spillway began to discharge at 7:08, June 7 , and the peak breach flow was $6,500 \mathrm{~m}^{3} / \mathrm{s}$, which occurred at $12: 30$, June 10 .

Xiaogangjian landslide dam was also formed by Wenchuan earthquake, which belongs to the second type (rockfall induced) of landslide dams. The landslide dam has two internal layers from dam crest to bottom, the upper part is composed of large blocks, while the lower part is mainly composed of highly fragmented debris. Xiaogangjian landslide dam has the height of about $72 \mathrm{~m}$, and width of $173 \mathrm{~m}$ on the crest, and a volume of $2 \times 106 \mathrm{~m}^{3}$. After the field reconnaissance, and comprehensively considered the factors of construction conditions and the available time for risk migration, a spillway with $8 \mathrm{~m}$ depth and $30 \mathrm{~m}$ bottom width was constructed on the left bank of the dam. The water began to discharge at 12:00, June 12, and the peak breach flow was $3,950 \mathrm{~m}^{3} / \mathrm{s}$, which occurred at 13:05, June 12 .

On October 10, 2018 and November 3, 2018, two successive landslides occurred at the border of Sichuan Province and Tibet
Autonomous Region, and totally blocked the Jinsha River twice at the same location. The first landslide dam breached naturally on October 12 due to the overtopping flow. In this study, the second Baige landslide dam which breached after the manual intervention is the study object. The Baige landslide dam belongs to the third type (debris flow induced) of landslide dams. The landslide dam is composed of loose debris, and there is no obvious layered structures. The total volume of Baige landslide dam was $3.7 \times 106 \mathrm{~m}^{3}$, with an average height of $96 \mathrm{~m}$. The excavated spillway in the dam crest has the depth of $13.48 \mathrm{~m}$ at the entrance, and the bottom width of $3 \mathrm{~m}$. The water began to discharge at 10:50, November 12, and the peak breach flow was $31000 \mathrm{~m}^{3} / \mathrm{s}$, which occurred at 18:00, November 13 .

\section{Calculated Results}

Based on the numerical model developed by the authors, the breach processes of the three cases have been simulated. The morphological, hydrodynamic, and mechanical parameters of the three landslide dams are listed in Table 1. The stratification of the landslide dams, physical and mechanical parameters of each layer are shown in Table 2 . The comparison of measured and calculated breaching parameters (i.e., peak breach flow, time to peak, final breach top width, final breach bottom width, final breach depth, and released water storage) of the three landslide dams are shown in Figure 5. 


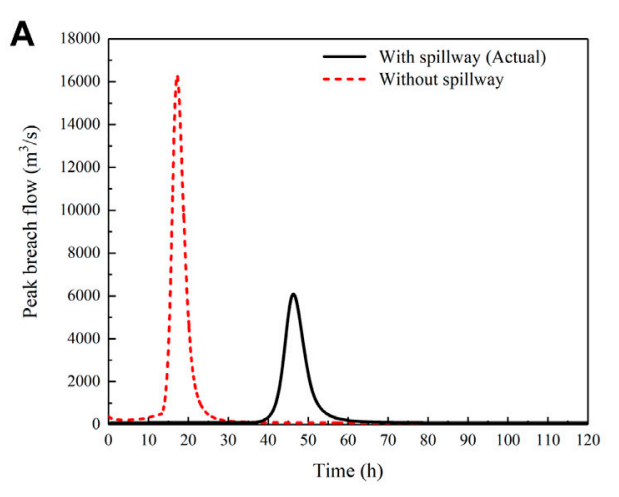

Breach hydrographs in the condition of with and without the spillway

C

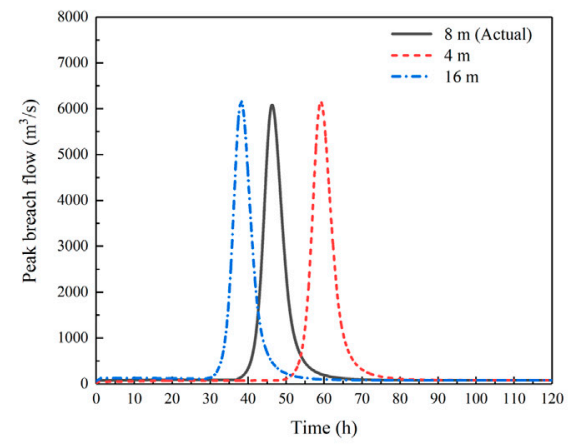

Breach hydrographs in the condition of with different bottom widths in the spillway

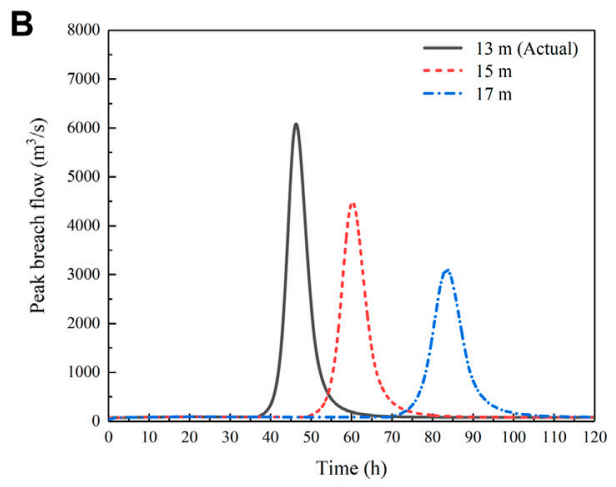

Breach hydrographs in the condition of with different depths in the spillway

D

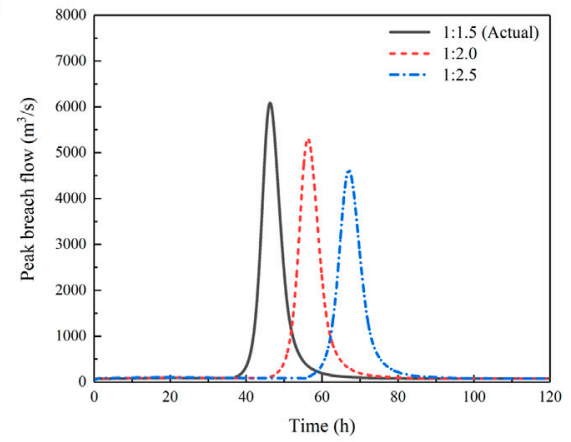

Breach hydrographs in the condition of with different slope ratios in cross-section in the spillway

E

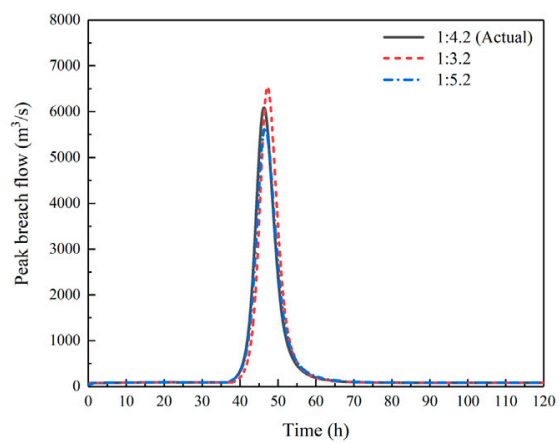

Breach hydrographs in the condition of with different slope ratios in longitudinal

section in the spillway

FIGURE 6 | Comparison of breach hydrographs of Tangjiashan landslide dam under different conditions. (A) Breach hydrographs in the condition of with and without the spillway. (B) Breach hydrographs in the condition of with different depths in the spillway. (C) Breach hydrographs in the condition of with different bottom widths in the spillway. (D) Breach hydrographs in the condition of with different slope ratios in cross-section in the spillway. (E) Breach hydrographs in the condition of with different slope ratios in longitudinal section in the spillway.

The comparison in Figure 5 shows that, for Tangjiashan landslide dam, the relative errors of all breaching parameters of are less than $\pm 15 \%$; for Xiaogangjian landslide dam, except for the final breach top width has a relative error of $71.8 \%$, the relative errors of all the other breaching parameters are less than $\pm 15 \%$; for Baige landslide dam, except for the final breach depth has a relative error of $36.7 \%$, the relative errors of all the other breaching parameters are less than $\pm 25 \%$. As the top layer of the Xiaogangjian landslide dam is composed of large grained rocks, the spillway is excavated with the help of the explosion. Hence, the erosion characteristics of landslide dam deposits in the breach channel become complex. In general, the numerical model developed by the authors gives reasonably calculated results for landslide dam breaching. The following section utilizes the numerical model to study the influence of spillway section morphologies on landslide dam breaching. 
A

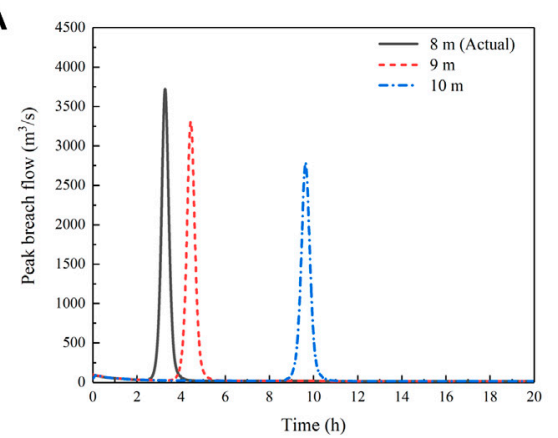

Breach hydrographs in the condition of with different depths in the spillway

B

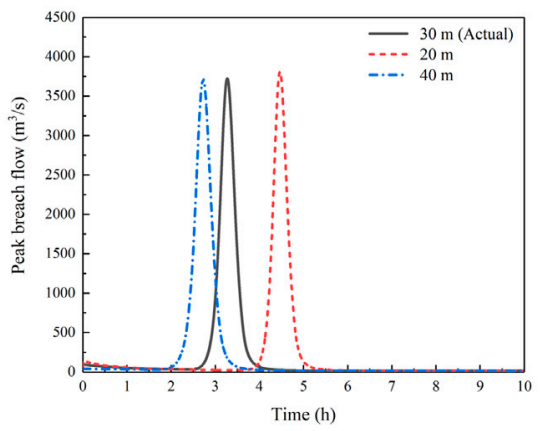

Breach hydrographs in the condition of with different bottom widths in the

C

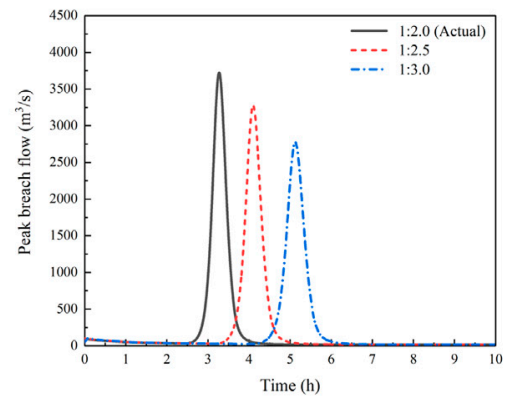

Breach hydrographs in the condition of with different slope ratios in cross-section

D

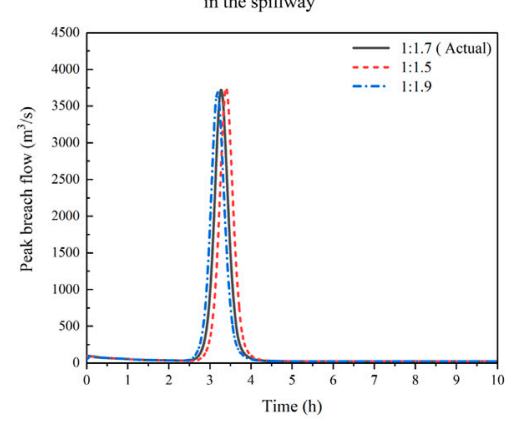

Breach hydrographs in the condition of with different slope ratios in longitudinal section in the spillway
FIGURE 7 | Comparison of breach hydrographs of Xiaogangjian landslide dam under different conditions. (A) Breach hydrographs in the condition of with different depths in the spillway. (B) Breach hydrographs in the condition of with different bottom widths in the spillway. (C) Breach hydrographs in the condition of with different slope ratios in cross-section in the spillway. (D) Breach hydrographs in the condition of with different slope ratios in longitudinal section in the spillway.

\section{COMPARISON OF BREACH PROCESSES OF LANDSLIDE DAMS WITH DIFFERENT SPILLWAY SECTION MORPHOLOGIES}

An ideal efficient spillway for landslide dam drainage should provide the following requirements: 1) Excavation should be conducted at the lower position of the dam crest, and the excavated volume should be relatively small. 2) In the initial stage of landslide dam breaching, the spillway bottom can be undercut immediately, thereby rapid increment of breach flow discharge and effective reduction the water level of the dammed lake can be maintained. 3) During the accelerated stage, although the breach bottom continues to undercut, the mass failures due to the instability of the breach side slope should be less likely to happen, and the outburst flood could run forward within the downstream channel. The breach hydrograph curve should exhibit a flat shape rather than a spike. 4) After landslide dam breaching, the downcutting depth of the breach should be large enough, which could effectively reduce the storage capacity of the dammed lake.

The cross section of the spillways of the selected Tangjiashan, Xiaogangjian, and Baige landslide dams is all trapezoidal. Here, ten conditions of spillways are set to comprehensively reflect the influence due to the variations of the spillway on the breach process of landslide dams. The first condition is the actual situation on-site, which is expounded in the "Case studies" section. The second condition is set as the landslide dams without spillways. In addition, eight other conditions aim to highlight the effect of variations in depth (conditions 3 and 4), bottom width (conditions 5 and 6), slope ratio in cross section (7 and 8), and longitudinal section (conditions 9 and 10) are also set for the comparison. The morphological parameters of spillways for each condition are listed in Table 3.

The comparison of measured and calculated results of Tangjiashan, Xiaogangiian, and Baige landslide dams under different conditions are shown in Tables 4-6, respectively. The relative change rates of breaching parameters calculated in Tables 4-6 are the errors between each corresponding condition and condition 1 . Since the breach flow discharge is the key to the disaster consequence, Figures 6-8 also presents the comparison of breach hydrographs of the three landslide dams under different conditions, respectively.

\section{With and Without Spillways}

The comparison in Figures 6A, 8A shows that excavating spillway or not has a significant influence on the three landslide dams' breach processes. For Tangjiashan and Baige landslide dams, it was observed that in the absence of a spillway, peak breach flow increases sharply, the volume of released water increases significantly, and the time to peak breach flow is shortened. This situation shows that if there is no spillway, severe disasters will occur. For Xiaogangjian landslide dam, without the spillway, it would not breach because the dam structure and the upper coarse particles have a strong anti-erosion ability, and the upstream flow is small to erode the landslide deposits. However, there still has the risk of dam failure in the future if the upstream inflow increases to a certain extent to wash the large particles away. 


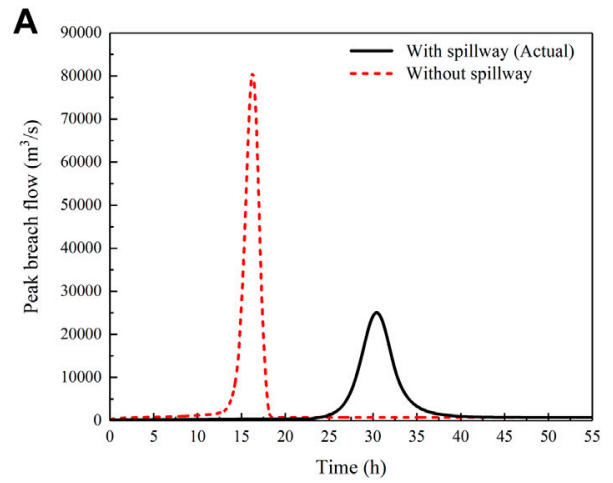

Breach hydrographs in the condition of with and without the spillway

C

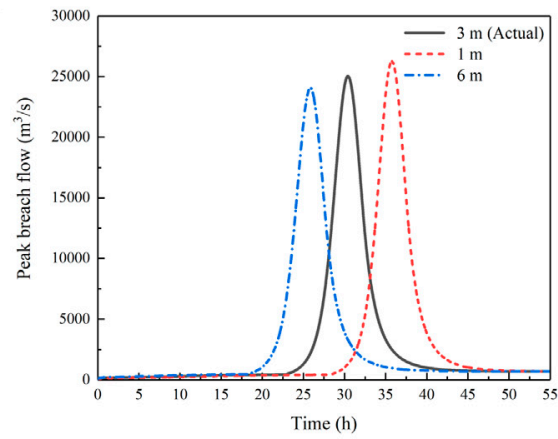

Breach hydrographs in the condition of with different bottom widths in the spillway
B

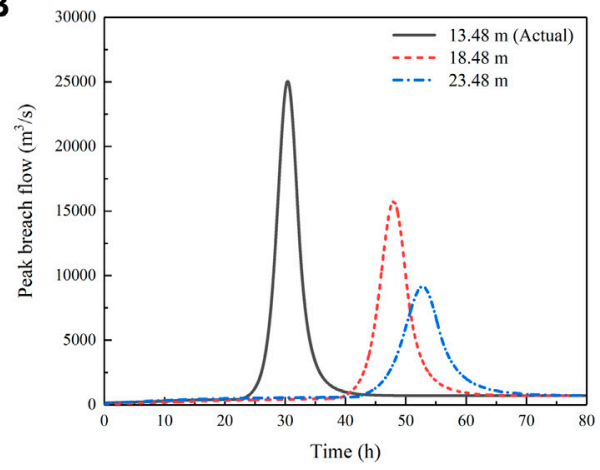

Breach hydrographs in the condition of with different depths in the spillway

D

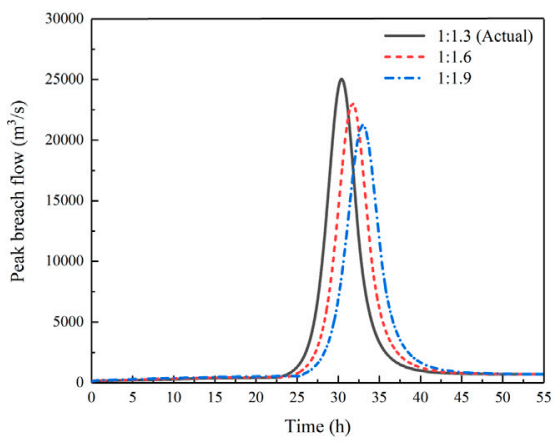

Breach hydrographs in the condition of with different slope ratios in cross-section in the spillway

E

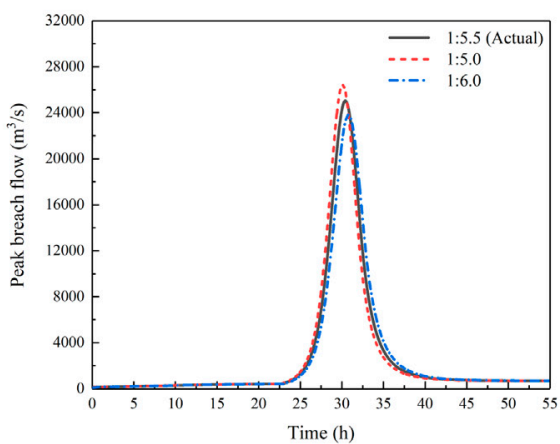

Breach hydrographs in the condition of with different slope ratios in longitudinal section in the spillway

FIGURE 8 | Comparison of breach hydrographs of Baige landslide dam under different conditions. (A) Breach hydrographs in the condition of with and without the spillway. (B) Breach hydrographs in the condition of with different depths in the spillway. (C) Breach hydrographs in the condition of with different bottom widths in the spillway. (D) Breach hydrographs in the condition of with different slope ratios in cross-section in the spillway. (E) Breach hydrographs in the condition of with different slope ratios in longitudinal section in the spillway.

\section{Different Spillway Depths}

The comparison in Figures 6B, 7A, 8B shows that spillway depth plays an essential role in the breach processes of the three landslide dams, and the influence on the three landslide dams demonstrates a similar regularity. With the increase of spillway depth, the water storage capacity of the dammed lake reduces, and the hydrodynamic conditions gradually weaken. The most distinctive feature observed in the landslide dam breaching due to the variations of spillway depth is that the peak breach flow discharge decreases sharply, while the time to peak delays. In addition, the final breach top and bottom widths decrease with the increasing spillway depth, mainly because it lies in the attenuation of erosion ability as the peak breach flow decreases.

\section{Different Spillway Bottom Widths}

The comparison in Figures 6C, 7B, 8C also shows that variation of spillway bottom width has a major impact on the time to peak for three landslide dams. It is worth mentioning that, for Tangjiashan and Xiaogangjian landslide dams, the variation of spillway bottom width has a little impact on the peak breach flow; however, for 
Baige landslide dam, as the bottom width increases, the peak breach flow reduces slightly obvious due to the relatively high soil erodibility. For the landslide dam with low erodibility, the size expansion rate of spillway is very small, as well as the released water storage in the initial stage of breach process; with the intensification of soil erosion, the evolution speed of breach size increases rapidly. Hence, for the landslide dam with low erodibility, the larger the spillway bottom width is, the earlier the time to peak occurs; while the peak breach flow changes a little. For the landslide dam with high erodibility, the increment of breach size is obvious, resulted in the large released water storage in the dammed lake in the initial stage; thus, for the landslide dam with high erodibility, the larger the spillway bottom width is, the earlier the time to peak occurs, and the smaller the peak breach flow is.

\section{Different Spillway Slope Ratios in the Cross and Longitudinal Sections}

The comparison in Figures 6D, 7C, 8D shows that variation of spillway slope ratios in the cross section, and the comparison in Figures 6E, 7D, 8E shows that variation of spillway slope ratios in the longitudinal section. The cross section area of the spillway increases with the decrease of the slope ratio in the cross section of the spillway, while the depth of water flow in the spillway decreases. This weakens the erosion ability of the breach flow and resulting in reduced peak breach flow and the delay of time to peak. It also simultaneously affects the size of the breach. When it comes to the slope ratio in the longitudinal section in the spillway, the comparison shows that this influencing factor has relatively little influence on the failure process.

\section{Different Simulation Methods}

In order to provide a method for optimal design of spillways to minimize the risks, based on Tangjiashan landslide dam case, Peng et al. (2014) quantitatively evaluate practical options for spillway design with a simplified physically-based dam breach model. According to the numerical simulation, Peng et al. (2014) concluded that, a spillway with a shallow-broad and deep-narrow cross sections are suitable for low and high erodibility landslide dams, respectively, while a spillway with a large slope ratio in longitudinal section is suitable for high erodibility landslide dams with large dam widths and gentle downstream dam slopes. In addition, lowering the spillway depth is more effective than widening the spillway width in spillway design.

Compared with the conclusions proposed by Peng et al. (2014), there are some similarities and differences between the two studies. The most important one is that two studies have confirmed that spillway depth is a dominant factors for risk mitigation. However, since the section areas of different spillways remained the same in the study of Peng et al. (2014), in addition, due to the characteristics of layered structure of landslide dams are not taken into account, the soil erodibility of Tangjiashan is identified as a high value in Peng et al. (2014), there are some differences lied in the conclusions. It is worth mentioning that, if the boundary conditions and input parameters are consistent, the calculated results and conclusions in this study are in accordance with those of Peng et al. (2014).

\section{CONCLUSION}

Considering the morphological, structural, and material characteristics of the landslide dams and the hydrodynamic conditions of dammed lakes, a numerical model was developed by the authors. Three failure cases with detailed measured data are used to discuss the effects of spillway section morphologies on landslide dam breach processes. The conclusions are drawn as follows:

1) Excavating a spillway can effectively reduce the peak breach flow, thus delay the time to peak discharge. It is worth noting that, for a landslide dam with fine particles at the bottom and large particles at the top, when the hydrodynamic conditions are weak, it may not breach without spillway, but there is still a risk of dam failure.

2) In the spillway excavation, increasing the spillway depth can effectively decrease the peak breach flow, delay the time to peak, and reduce the released water storage in the dammed lake. Therefore, where conditions are concerned, care should be taken to dig as deep a spillway as possible.

3) Spillway bottom width is also an important influencing factor for the discharge efficiency, which has a major effect on time to peak, but conversely has a minor effect on the peak breach flow for the landslide dam with low erodibility. Larger spillway bottom width corresponds to the earlier time to peak, and it is also an important way to reduce the peak breach flow for the landslide dam with large erodibility.

4) A gentle slope ratio in the cross section of the spillway can decrease the peak breach flow and delay the time to peak; thus, it is recommended to reduce the slope ratio of the spillway cross section as much as possible. Moreover, the slope ratio in the longitudinal section in the spillway has little influence on the breach process.

\section{DATA AVAILABILITY STATEMENT}

The raw data supporting the conclusions of this article will be made available by the authors, without undue reservation.

\section{AUTHOR CONTRIBUTIONS}

MY: writing-original draft, calculation, and analysis. QZ: supervision, methodology, and funding acquisition. SM: methodology and revision. YS: methodology and advice. All authors contributed to the article and approved the submitted version.

\section{FUNDING}

This work was financially supported by the National Key Research and Development Program of China (Grant No. 2018YFC1508604), the National Natural Science Foundation of China (Grant Nos. U2040221 and 51779153), and the Fundamental Research Funds for Central Public Research Institutes (Grant No. Y320005). 


\section{REFERENCES}

Berrocal, J., Espinosa, A. F., and Galdos, J. (1978). Seismological and Geological Aspects of the Mantaro Landslide in Peru. Nature 275, 533-536. doi:10.1038/ 275533a0

Cai, Y., Cheng, H., Wu, S., Yang, Q., Wang, L., Luan, Y., et al. (2020). Breaches of the Baige Barrier lake: Emergency Response and Dam Breach Flood. Sci. China Technol. Sci. 63 (7), 1164-1176. doi:10.1007/s11431019-1475-y

Cai, Y. J., Luan, Y. S., Peng, W. X., Li, J. Q., and Xu, Y. (2021). Analysis on Typical Cases of Barrier lake: Cause, Disaster and Emergency Response. Wuhan, China: Changjiang River publication. (in Chinese).

Chen, S. J., Chen, Z. Y., Tao, R., Yu, S., Xu, W. J., Zhou, X. B., et al. (2018). Emergency Response and Back Analysis of the Failures of Earthquake Triggered cascade Landslide Dams on the Mianyuan River, China. Nat. Hazards Rev. 19 (3), 05018005. doi:10.1061/(ASCE)NH.1527-6996.0000285

Chen, S. S., Zhao, T. L., and Zhong, Q. M. (2015). Dam-break Numerical Model for a Barrier Dam and its Application. Hydro-Science Eng. 3, 1-8. (in Chinese). doi:10.16198/j.cnki.1009-640X.2015.03.001

Chen, Z. Y., Ma, L. Q., Yu, S., Chen, S. J., Zhou, X. B., Sun, P., et al. (2015). Back Analysis of the Draining Process of the Tangjiashan Barrier lake. J. Hydraulic Eng. 141 (4), 05014011. doi:10.1061/(asce)hy.19437900.0000965

Costa, J. E., and Schuster, R. L. (1988). The Formation and Failure of Natural Dams. Geol. Soc. America Bull. 100 (7), 1054-1068. doi:10.1130/0016-7606(1988) $100<1054$ :tfafon $>2.3 . \mathrm{co} ; 2$

Cui, P., Zhu, Y.-y., Han, Y.-s., Chen, X.-q., and Zhuang, J.-q. (2009). The 12 May Wenchuan Earthquake-Induced Landslide Lakes: Distribution and Preliminary Risk Evaluation. Landslides 6 (3), 209-223. doi:10.1007/ s10346-009-0160-9

Fan, X., Dufresne, A., Siva Subramanian, S., Strom, A., Hermanns, R., Tacconi Stefanelli, C., et al. (2020). The Formation and Impact of Landslide Dams State of the Art. Earth-Science Rev. 203, 103116. doi:10.1016/ j.earscirev.2020.103116

Li, L., Yang, X., Zhou, J., Zhang, J., and Fan, G. (2021). Large-scale Field Test Study on Failure Mechanism of Non-cohesive Landslide Dam by Overtopping. Front. Earth Sci. 9, 660408. doi:10.3389/feart.2021.660408

Liao, H.-m., Yang, X.-g., Lu, G.-d., Tao, J., and Zhou, J.-w. (2019). Experimental Study on the River Blockage and Landslide Dam Formation Induced by Rock Slides. Eng. Geology. 261, 105269. doi:10.1016/j.enggeo.2019.105269

Liu, N., Chen, Z., Zhang, J., Lin, W., Chen, W., and Xu, W. (2010). Draining the Tangjiashan Barrier lake. J. Hydraul. Eng. 136 (11), 914-923. doi:10.1061/(asce) hy.1943-7900.0000241

Mei, S., Chen, S., Zhong, Q., and Shan, Y. (2021). Effects of Grain Size Distribution on Landslide Dam Breaching-Insights from Recent Cases in China. Front. Earth Sci. 9, 658578. doi:10.3389/feart.2021.658578

Peng, M., Ma, C. Y., Chen, H. X., Zhang, P., Zhang, L. M., Jiang, M. Z., et al. (2021). Experimental Study on Breaching Mechanisms of Landslide Dams Composed of Different Materials under Surge Waves. Eng. Geology. 291, 106242. doi:10.1016/j.enggeo.2021.106242

Peng, M., Zhang, L. M., Chang, D. S., and Shi, Z. M. (2014). Engineering Risk Mitigation Measures for the Landslide Dams Induced by the 2008 Wenchuan Earthquake. Eng. Geology. 180, 68-84. doi:10.1016/ j.enggeo.2014.03.016

Schuster, R. L., and Evans, S. G. (2011). Engineering Measures for the hazard Reduction of Landslide Dams. Berlin, Germany: Springer Berlin Heidelberg. doi:10.1007/978-3-642-04764-0_2

Shan, Y., Chen, S., and Zhong, Q. (2020). Rapid Prediction of Landslide Dam Stability Using the Logistic Regression Method. Landslides 17 (12), 2931-2956. doi:10.1007/s10346-020-01414-6

Shang, Y., Yang, Z., Li, L., Liu, D. A., Liao, Q., and Wang, Y. (2003). A Super-large Landslide in Tibet in 2000: Background, Occurrence, Disaster, and Origin. Geomorphology 54, 225-243. doi:10.1016/S0169-555X(02)00358-6

Shi, Z. M., Zheng, H. C., Peng, M., and Zhang, L. M. (2016). Breaching Mechanism Analysis of Landslide Dams Considering Different Spillway Schemes - A Case
Study of Tangiiashan Landslide Dam. J. Eng. Geology. 24 (5), 741-751. (in Chinese). doi:10.13544/j.cnki.jeg.2016.05.003

Takayama, S., Miyata, S., Fujimoto, M., and Satofuka, Y. (2021). Numerical Simulation Method for Predicting a Flood Hydrograph Due to Progressive Failure of a Landslide Dam. Landslides 18 (11), 3655-3670. doi:10.1007/s10346021-01712-7

Yang, Y., Cao, S.-y., Yang, K.-j., and Li, W.-p. (2015). Experimental Study of Breach Process of Landslide Dams by Overtopping and its Initiation Mechanisms. J. Hydrodyn 27 (6), 872-883. doi:10.1016/S1001-6058(15) 60550-9

Yin, Y., Wang, F., and Sun, P. (2009). Landslide Hazards Triggered by the 2008 Wenchuan Earthquake, Sichuan, China. Landslides 6 (2), 139-152. doi:10.1007/ s10346-009-0148-5

You, Y., Liu, J. F., and Chen, X. Z. (2012). Design of Sluiceway Channel in a Landslide Dam Triggered by the Wenchuan Earthquake. Disaster Adv. 5 (4), 241-249. doi:10.2151/jmsj.2012-516

Zhang, J.-y., Fan, G., Li, H.-b., Zhou, J.-w., and Yang, X.-g. (2021). Large-scale Field Model Tests of Landslide Dam Breaching. Eng. Geology. 293, 106322. doi:10.1016/j.enggeo.2021.106322

Zhao, T., Chen, S., Fu, C., and Zhong, Q. (2019). Centrifugal Model Test on the Failure Mechanism of Barrier Dam Overtopping. KSCE J. Civ Eng. 23 (4), 1548-1559. doi:10.1007/s12205-019-0375-9

Zhao, T., Chen, S., Fu, C., and Zhong, Q. (2018). Influence of Diversion Channel Section Type on Landslide Dam Draining Effect. Environ. Earth Sci. 77 (2), 54-62. doi:10.1007/s12665-017-7217-1

Zhao, W. Y., Chen, X. Q., Gao, Q., and Jia, S. T. (2011). Experimental Study of Dam-Break of Earthquake Barrier lake with Different Cross Sections of Drainage Channel. J. Sediment Res. 4, 29-37. (in Chinese). doi:10.16239/ j.cnki.0468-155x.2011.04.009

Zhong, Q., Chen, S., and Shan, Y. (2020a). Prediction of the Overtopping-Induced Breach Process of the Landslide Dam. Eng. Geology. 274, 105709. doi:10.1016/ j.enggeo.2020.105709

Zhong, Q., Chen, S., Wang, L., and Shan, Y. (2020b). Back Analysis of Breaching Process of Baige Landslide Dam. Landslides 17 (7), 1681-1692. doi:10.1007/ s10346-020-01398-3

Zhong, Q. M., Chen, S. S., Mei, S. A., and Cao, W. (2018). Numerical Simulation of Landslide Dam Breaching Due to Overtopping. Landslides 15 (6), 1183-1192. doi:10.1007/s10346-017-0935-3

Zhong, Q., Wang, L., Chen, S., Chen, Z., Shan, Y., Zhang, Q., et al. (2021). Breaches of Embankment and Landslide Dams - State of the Art Review. Earth-Science Rev. 216, 103597. doi:10.1016/j.earscirev.2021.103597

Zhou, G. G. D., Zhou, M., Shrestha, M. S., Song, D., Choi, C. E., Cui, K. F. E., et al. (2019). Experimental Investigation on the Longitudinal Evolution of Landslide Dam Breaching and Outburst Floods. Geomorphology 334, 29-43. doi:10.1016/ j.geomorph.2019.02.035

Zhu, X., Liu, B., Peng, J., Zhang, Z., Zhuang, J., Huang, W., et al. (2021). Experimental Study on the Longitudinal Evolution of the Overtopping Breaching of Noncohesive Landslide Dams. Eng. Geology. 288, 106137. doi:10.1016/j.enggeo.2021.106137

Conflict of Interest: The authors declare that the research was conducted in the absence of any commercial or financial relationships that could be construed as a potential conflict of interest.

Publisher's Note: All claims expressed in this article are solely those of the authors and do not necessarily represent those of their affiliated organizations, or those of the publisher, the editors, and the reviewers. Any product that may be evaluated in this article, or claim that may be made by its manufacturer, is not guaranteed or endorsed by the publisher.

Copyright (c) 2021 Yang, Zhong, Mei and Shan. This is an open-access article distributed under the terms of the Creative Commons Attribution License (CC BY). The use, distribution or reproduction in other forums is permitted, provided the original author(s) and the copyright owner(s) are credited and that the original publication in this journal is cited, in accordance with accepted academic practice. No use, distribution or reproduction is permitted which does not comply with these terms. 